\title{
Steady-state critical loads of acidity for forest soils in the Georgia Basin, British Columbia
}

\author{
Alyse MONGEON, Julian AHERNE* and Shaun A. WATMOUGH \\ Environmental and Resources Studies, Trent University, 1600 West Bank Drive, Peterborough, ON K9J 7B8, Canada \\ *e-mail corresponding author: julian.aherne@ucd.ie
}

\begin{abstract}
There has been growing interest in acid rain research in western Canada where sulphur (S) and nitrogen (N) emissions are expected to increase during the next two decades. One region of concern is southern British Columbia, specifically the Georgia Basin, where emissions are expected to increase owing to the expansion of industry and urban centres (Vancouver and Victoria). In the current study, weathering rates and critical loads of acidity ( $S$ and $N$ ) for forest soils were estimated at nineteen sites located within the Georgia Basin. A base cation to aluminium ratio of 10 was selected as the critical chemical criterion associated with ecosystem damage. The majority of the sites (58\%) had low base cation weathering rates $\left(\leq 50 \mathrm{meq} \mathrm{m}^{-2} \mathrm{y}^{-1}\right)$ based on the PROFILE model. Accordingly, mean critical load for the study sites, estimated using the steady-state mass balance model, ranged between 129-168 meq $\mathrm{m}^{-2} y^{-1}$. Annual average total (wet and dry) $S$ and $N$ deposition during the period 2005-2006 (estimated by the Community Multiscale Air Quality model), exceeded critical load at five-nine of the study sites (mean exceedance $=32-46$ meq $m^{-2}$ $\left.y^{-1}\right)$. The high-elevation $(>1000 \mathrm{~m})$ study sites had shallow, acid sensitive, soils with low weathering rates; however, critical loads were predominantly exceeded at sites close to Vancouver under higher modelled deposition loads. The extent of exceedance is similar to other industrial regions in western and eastern Canada.
\end{abstract}

Key words: steady-state mass balance (SSMB) model, sulphur, nitrogen, exceedance, weathering rates, PROFILE, Canada

\section{INTRODUCTION}

Acid deposition has been a major environmental issue in eastern North America and Europe for decades, owing to the high levels of acid deposition and negative impacts on surface waters and forest soils. Recently there has been growing interest in western Canada where sulphur $(\mathrm{S})$ and nitrogen $(\mathrm{N})$ emissions are expected to increase. One region of concern is southwestern British Columbia, specifically the Georgia Basin, where emissions are expected to increase owing to the expansion of industry and urban centres (Vancouver and Victoria) and the transportation sector (road vehicles and marine vessels; Fraser et al. 2006).

The critical load approach is used by policy makers in Europe to formulate emission reduction policies (Johansson et al. 2001). Critical loads are defined as a 'quantitative estimate of an exposure to one or more pollutants below which significant harmful effects on specified sensitive elements of the environment do not occur, according to our present knowledge' (Nilsson \& Grennfelt 1988). Critical loads link deposition to a chemical variable (the 'chemical criterion') in the soil, or soil solution, associated with ecosystem effects. The violation of a specific value (the 'critical limit') for the chemical criterion is associated with ecosystem damage (Hall et al. 2001a). The steady-state mass balance (SSMB) model is widely used for estimating critical loads of acidity for forest soils (Grennfelt et al. 2001; Ouimet et al. 2006; Whitfield et al. 2010, this issue).
The most widely used soil chemical criterion is based on the ratio of base cations $(\mathrm{Bc})$ and aluminium $(\mathrm{Bc}: \mathrm{Al})$ in soil solution. In eastern Canada, a critical limit of $\mathrm{Bc}: \mathrm{Al}=10$ has been used to maintain soil base saturation (Ouimet et al. 2006).

The chemical weathering of soil minerals provides forest ecosystems with long-term buffering capacity against acidification (Warfvinge \& Sverdrup 1992); as such (base cation) weathering is a key determinant of critical loads. Soils with low weathering rates are inherently sensitive to acid deposition. A number of different methods have been developed to calculate weathering rates (Melkreud et al. 2003; Whitfield et al. 2006); however, the most robust methods are based on soil mineralogy. PROFILE is a process-oriented soil chemical model that uses independent soil properties (including mineralogy) to calculate weathering rates (Warfvinge \& Sverdrup 1992).

The Georgia Basin has long been recognised as highly sensitive to acid deposition because the region is dominated by base-poor geologies with poor weathering capacity (Wiens 1987). A recent survey of high-elevation lakes $(n=72)$ in the Georgia Basin suggested that approximately $20 \%$ received S deposition in excess of their critical load (Strang et al. 2010, this issue). The objective of this study was to assess the potential impacts of current $\mathrm{S}$ and $\mathrm{N}$ deposition on forest soils in the Georgia Basin. Base cation weathering rates and critical loads of acidity were estimated for nineteen study sites located across the Georgia Basin. Weather- 


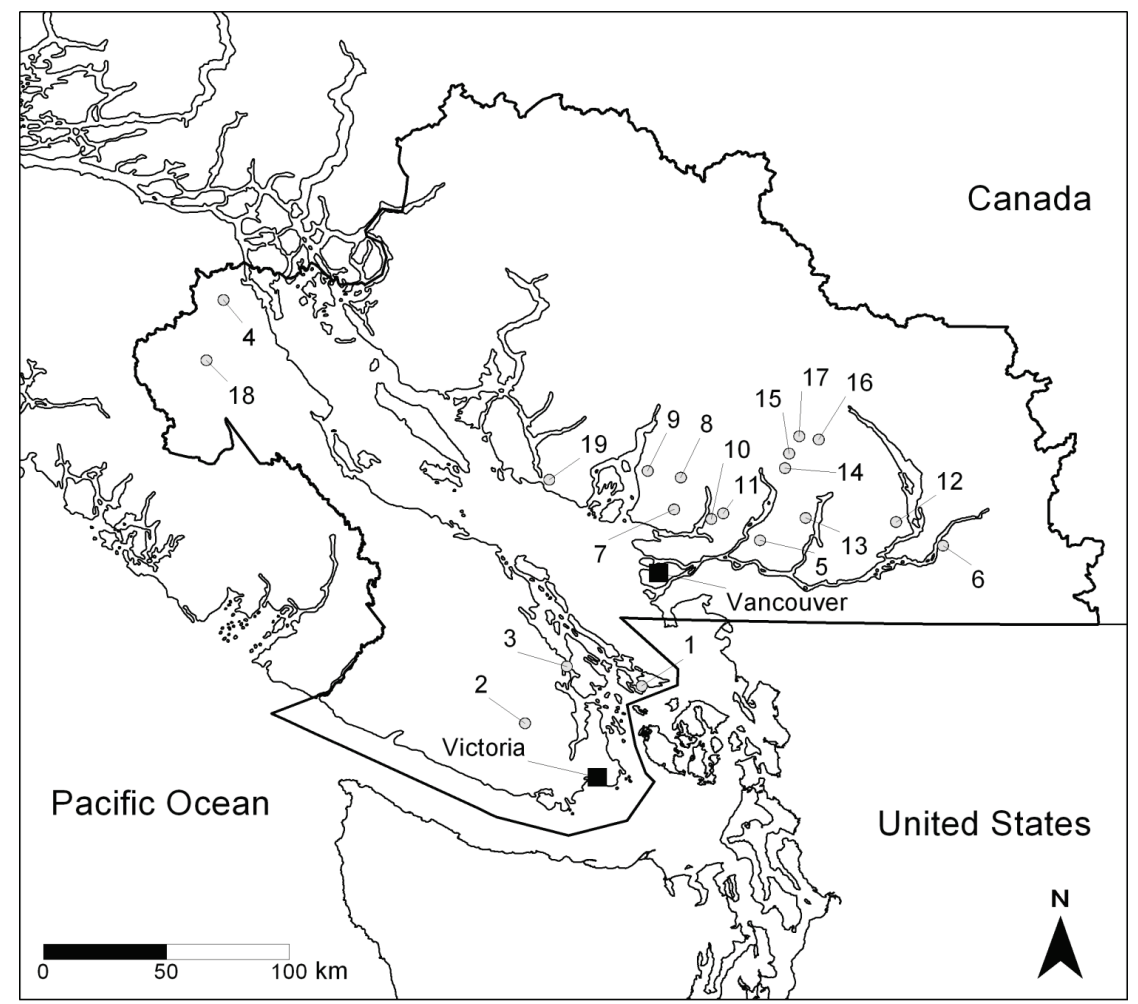

Fig. 1. Location of study sites (circles; $n=19$ ) within the Georgia Basin (thick black line). Cities are also shown (black squares). The site ID (numeric descriptors) are described in table 1.

ing rates were estimated using the PROFILE model, and critical loads were estimated using the SSMB model following the approach used in eastern Canada (Ouimet et al. 2006).

\section{METHODS}

\subsection{Study area}

The Georgia Basin, which covers an area of approximately $48,000 \mathrm{~km}^{2}$ in south-western, British Columbia (Fig. 1), is part of a larger basin under the jurisdiction of Canada (Georgia Basin) and the United States of America (Puget Sound). The Basin is ringed by the Olympic mountains, Vancouver island ranges, Coast ranges and the Cascades which trap air masses and lead to the build up of air borne pollutants. The air quality in the Lower Fraser valley in the Georgia Basin regularly exceeds national guidelines (Fraser et al. 2006). The basin encompasses seven biogeoclimatic ecosystem classification (BEC) zones: coastal Douglas fir (CDF), coastal western hemlock $(\mathrm{CWH})$, mountain hemlock $(\mathrm{MH})$, interior Douglas fir, montane spruce, Engelmann spruce-subalpine fir and the alpine tundra zones (Meidinger \& Pojar 1991).

Base cation weathering rates and critical loads of acidity ( $\mathrm{S}$ and $\mathrm{N}$ ) were estimated for forest soils at nineteen sites across the Georgia Basin (Fig. $1 \&$ Tab. 1). Eleven of the study sites were forest plots within the former Acid Rain National Early Warning System (ARNEWS) program, six of the sites were high-eleva- tion lake catchments surveyed by Environment Canada for water quality (Strang et al. 2010, this issue), and the remaining two sites were long-term intensive research catchments (Malcolm Knapp Research Forest (Feller 2010, this issue) and Roberts Creek). Exceedance, defined as the amount of $\mathrm{S}$ and $\mathrm{N}$ deposition in excess of the critical load, was determined for each study site. Annual average total (wet and dry) S and $\mathrm{N}$ deposition for the period 2005-2006 was obtained from the Community Multiscale Air Quality (CMAQ: di Cenzo \& Lepage 2003) model at a $4 \mathrm{~km}$ by $4 \mathrm{~km}$ grid resolution.

\subsection{Soil data}

Soils were sampled during July 2006, with at least one soil pit dug down to the $\mathrm{C}$ horizon or to the bedrock at each study site; more than one soil pit (two-five) was dug at the high-elevation sites, Malcolm Knapp Research Forest and Roberts Creek, to provide a better representation of soils in these catchments. The forest floor (litter, fribic and humic (LFH) layers) was sampled using a $0.25 \mathrm{~m}^{2}$ quadrate. Mineral soil ( $\left.100 \mathrm{~g}\right)$ was sampled by horizon for chemical analysis. The depth of each soil horizon, including the LFH, was measured and percent stone content visually estimated for each pit. In the laboratory, mineral soils were air dried and sieved through a $2 \mathrm{~mm}$ mesh. The LFH samples were dried, ground using a Wiley mill, and weighed.

Exchangeable base cations $\left(\mathrm{Ca}^{2+}, \mathrm{Mg}^{2+}, \mathrm{Na}^{+}\right.$and $\left.\mathrm{K}^{+}\right)$ were measured by atomic absorption spectrometry 
Tab. 1. Site ID, name, location (longitude, latitude), altitude, soil pit depth, $\mathrm{pH}$, loss-on-ignition (LOI), cation excange capacity (CEC), base saturation (BS), gibbsite equilibrium constant (site-specific $\mathrm{K}_{\text {gibb}}$ ), percent clay content, biogeoclimatic ecosystem classification (BEC) zone and data source or network (SRC) for the nineteen study sites in the Georgia Basin, British Columbia. ARN (Acid Rain National Early Warning System), EC (Environment Canada), CFS (Canadian Forest Service) and FBC (Ministry of Forestry, British Columbia).

\begin{tabular}{|c|c|c|c|c|c|c|c|c|c|c|c|c|c|}
\hline ID & Site name & $\frac{\text { Longitude }}{\text { decimal }}$ & $\frac{\text { Latitude }}{\text { degrees }}$ & $\begin{array}{c}\text { Alt. } \\
\mathrm{m}\end{array}$ & $\begin{array}{l}\text { Depth } \\
\mathrm{m}\end{array}$ & $\begin{array}{c}\mathrm{pH} \\
\mathrm{H}_{2} \mathrm{O}\end{array}$ & $\begin{array}{l}\text { LOI } \\
\%\end{array}$ & $\begin{array}{c}\mathrm{CEC} \\
\text { meq kg-1 }\end{array}$ & $\begin{array}{l}\mathrm{BS} \\
\%\end{array}$ & $\begin{array}{c}K_{\text {gibb }} \\
\log \end{array}$ & $\begin{array}{c}\text { Clay } \\
\%\end{array}$ & $\begin{array}{l}\text { BEC } \\
\text { zone }\end{array}$ & $\mathrm{SRC}$ \\
\hline 1 & Saturna Island & -123.14 & 48.77 & 150 & 0.81 & 5.68 & 5.3 & 55.6 & 40.4 & 12.0 & 4.4 & $\mathrm{CDF}$ & $\mathrm{ARN}$ \\
\hline 2 & Shawnigan Lake & 72 & 48.63 & 366 & 0.63 & 5.22 & 7.1 & 72.2 & 26.4 & 10.8 & 9.2 & $\mathrm{CWH}$ & ARN \\
\hline 3 & Salt Spring & 123.52 & 48.83 & 122 & 0.46 & 5.39 & 10.6 & 92.4 & 37.0 & 10.3 & 7.9 & $\mathrm{CDF}$ & ARN \\
\hline 4 & Campbell River & -125.35 & 50.04 & 191 & 0.18 & 4.80 & 6.7 & 72.6 & 23. & 9. & 3.4 & $\mathrm{CWH}$ & ARN \\
\hline 5 & Malcolm Knapp & -122.56 & 49.28 & 366 & 0.47 & 4.79 & 14.2 & 83.0 & 10. & 8. & 4.7 & $\mathrm{CWH}$ & ARN \\
\hline 6 & Chilliwack & -121.63 & 49.27 & 489 & 0.27 & 4.18 & 24.1 & 135.8 & 14 & 6. & 2.4 & $\mathrm{CWH}$ & ARN \\
\hline 7 & Seymour E & -123.00 & 49.38 & 135 & 0.53 & 4.38 & 20.0 & 79.0 & 11.4 & 7. & 3.6 & $\mathrm{CWH}$ & ARN \\
\hline 8 & Seymour M-L & -122.97 & 49.49 & 342 & 0.67 & 4.72 & 17.8 & 82.4 & 5.7 & 8. & 2.7 & $\mathrm{CWH}$ & ARN \\
\hline 9 & Capilano & -123.14 & 49.51 & 100 & 0.51 & 4.36 & 21.3 & 88.5 & 5.1 & 7. & 2.3 & $\mathrm{CWH}$ & ARN \\
\hline 10 & Coquitlam W & -122.81 & 49.35 & 223 & 0.3 & 4.81 & 12.2 & 94.1 & 18 & 8. & 2.4 & $\mathrm{CWH}$ & ARN \\
\hline 11 & $\operatorname{lam} 110$ & -122 & 49. & 382 & 0.4 & 4.54 & 20. & 123.3 & & 7. & 3.6 & CWH & ARN \\
\hline 12 & Weaver lake & -121.87 & 49.35 & 509 & 0.23 & 4.61 & 13.4 & 120.1 & 20.2 & 7.9 & 8.9 & $\mathrm{CWH}$ & EC \\
\hline 13 & Florence Lake & -122.33 & 49.36 & 416 & 0.4 & 4.83 & 17.6 & 117.4 & 8.3 & 8.9 & 4.0 & $\mathrm{CWH}$ & EC \\
\hline 14 & Tingle Lake & -122.44 & 49.53 & 1006 & 0.1 & 4.38 & 27.2 & 158.0 & 12.1 & 6.1 & 0.9 & MH & EC \\
\hline 15 & Thomas Lake & -122.42 & 49.58 & 1014 & 0.1 & 4.36 & 18.8 & 187.7 & 9.3 & 6.2 & 1.9 & MH & EC \\
\hline 16 & Tretheway Lake & -122 & 49.63 & 137 & 0. & 4.72 & 23. & 131.8 & 3. & 8. & 2.7 & $\mathrm{MH}$ & EC \\
\hline 17 & Kinnear Lake & -122.37 & 49.6 & 1210 & 0.2 & 4.6 & 18. & 126.9 & 7.5 & 7. & 3.1 & $\mathrm{MH}$ & EC \\
\hline 18 & MASS & -125.42 & 49.83 & 701 & 0.3 & 4.58 & 40.6 & 97.2 & 29.8 & 7.6 & 10.1 & $\mathrm{CWH}$ & CFS \\
\hline \multirow[t]{2}{*}{19} & Roberts Creek & -123.64 & 49.47 & 461 & 0.35 & 5.14 & 5.4 & 38.7 & 10.1 & 9.8 & 3.8 & CWH & $\mathrm{FBC}$ \\
\hline & Average & & & 503 & 0.40 & 4.74 & 17.1 & 103.0 & 16.2 & 8.4 & 4.0 & & \\
\hline
\end{tabular}

(Varian AA 240FS) after extraction with a $1.0 \mathrm{M} \mathrm{NH}_{4} \mathrm{Cl}$ solution. Total cation exchange capacity (CEC) was measured by colourimetery (Pulse Autoanalyzer System) following subsequent extraction with a $2.0 \mathrm{M} \mathrm{NaCl}$ solution. Base saturation (BS) was estimated as the percentage of cation exchange sites occupied by base cations. The $\mathrm{pH}$ was measured in distilled water with a glass electrode Oakton $\mathrm{pH} / \mathrm{MVC}$ meter. Soil samples for the $\mathrm{B}$ horizons, or composites of $\mathrm{A}$ and $\mathrm{B}$ horizons (where A horizon was significant), representing the rooting zone were analysed for quantitative soil mineralogy by X-ray diffraction using a Siemens (Bruker) D5000 Bragg-Brentano diffractometer. Particle size analysis (sand, silt and clay) was measured using a Horiba Partica LA-950 and used to calculate soil surface area following Warfvinge \& Sverdrup (1992). Loss-onignition (LOI) was determined by igniting samples in a muffle furnace at $450{ }^{\circ} \mathrm{C}$ for 8 hours. Soil bulk density (BD) was estimated from LOI according to Siltanen et al. $(1997: \mathrm{BD}=0.075+1.301 \times \exp (-0.06 \times \mathrm{LOI}))$. Average soil physico-chemical data for each study site were weighted by depth and bulk density according to Helliwell et al. (1998).

\subsection{Base cation weathering rate}

The soil base cation weathering rate for the rooting zone was estimated using the PROFILE model (Warfvinge \& Sverdrup 1992), a steady-state soil chemistry model primarily driven by soil mineralogy, mineral surface area and moisture content (Warfvinge \& Sverdrup 1992; Melkreud et al. 2003). The weathering rate is proportional to the exposed surface area of the mineral and the activity of the exposed mineral is dependent on soil moisture. Reactions only take place on wetted surfaces, with the degree of surface wetting proportional to the soil moisture saturation. PROFILE has been widely used in Europe and North America to estimate weathering rates (Barkman \& Alveteg 2001; van der Salm 2001; Solberg et al. 2002; Melkreud et al. 2003; Ouimet \& Duchesne 2005; Whitfield et al. 2006). The inputs for PROFILE were averaged for the A and B horizons and did not include the LFH layer (which is generally devoid of minerals). Moisture content was set using regional default values that ranged between 0.30 and $0.35 \mathrm{~m}^{3} \mathrm{~m}^{-3}$.

A number of methods are available for estimating weathering rates (see Whitfield et al. 2006; Whitfield et al. 2010, this issue). While mineralogy-based approaches, such as PROFILE, are preferred, empiricalbased approaches, such as soil texture approximation (STA; UBA 2004), have the appeal of being based on widely available data and being 'regionally applicable'. In the current study, the relationship between soil parameters (e.g., LOI, clay, pH, etc., Tab. 1) and PROFILE-based weathering rates was evaluated using simple multiple regression. All variables (dependent and independent) were $\log$ transformed prior to regression analysis to ensure normality and equal variance.

\subsection{Steady-state mass balance model}

The critical load of acidity ( $\mathrm{S}$ and $\mathrm{N}$ ) for each of the study sites was estimated using the SSMB model, which is a single layer model where the soil is treated as one homogeneous compartment. The model is based on bal- 
ancing the inputs of acidity against sinks and outputs (UBA 2004):

$$
\begin{gathered}
C L(S+N)=B C_{d e p}-C l_{d e p}+B C_{w}- \\
-B c_{u}+N_{i}+N_{u}+N_{d e}-A N C_{\text {le(crit })}
\end{gathered}
$$

where $B C$ refers to base cations $\left(B C=\mathrm{Bc}+\mathrm{Na}^{+}, B c=\right.$ $\left.\mathrm{Ca}^{2+}+\mathrm{Mg}^{2+}+\mathrm{K}^{+}\right)$and the subscripts $d e p, w, u, i, d e$ and le refer to deposition, weathering, uptake, immobilisation, denitrification and leaching, respectively. Base cation and chloride $\left(\mathrm{Cl}^{-}\right)$deposition were estimated using a polynomial regression model (Aherne et al. 2008 , this issue). Base cation deposition was corrected for sea salt using theoretical sea salt ratios and assuming that all $\mathrm{Cl}^{-}$in precipitation originated from sea salt (e.g., (eq) ratio for $\mathrm{Ca}^{2+}: \mathrm{Cl}^{-}$is $0.037: 1$; UBA 2004). It was assumed there was no forest harvesting (uptake removal), as such, $N_{u}$ and $B c_{u}$ were set to zero. Default regional values for $N_{i}$ and $N_{d e}$ were taken from litera-

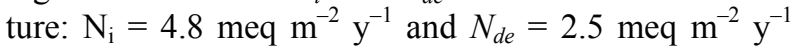
(Feller \& Kimmins 1984). $A N C_{\text {le(crit) }}$ is the critical (or acceptable) leaching of $A N C$ (Acid Neutralizing Capacity) defined as:

$$
\begin{aligned}
& A N C_{\text {le(crit) }}=-Q^{\frac{2}{3}} \cdot\left(1.5 \cdot\left(\frac{B c_{w}+B c_{d e p}-B c_{u}}{(B c: A l)_{c r i t} \cdot K_{\text {gibb }}}\right)\right)^{\frac{1}{3}}- \\
& -1.5 \cdot\left(\frac{B c_{w}+B c_{d e p}-B c_{u}}{(B c: A l)_{c r i t}}\right)
\end{aligned}
$$

where $Q$ is the annual water flux ( $\mathrm{mm}$ ) through the soil at the bottom of the rooting zone (soil percolation), $(B c: A l)_{c r i t}$ is the chemical criterion associated with ecosystem damage and $K_{\text {gibb }}$ is the gibbsite equilibrium constant that describes the relationship between $\mathrm{Al}^{3+}$ and $\mathrm{H}^{+}$in soil solution. In the current study, soil percolation was determined from long-term (1961-1990) average monthly temperature, precipitation, and cloudiness derived from a $0.5^{\circ} \times 0.5^{\circ}$ resolution global database (New et al. 1999). See Gibson et al. (2010, this issue) for further details. The $(B c: A l)_{c r i t}$ was based on a default value of 10, which has been used in eastern and western Canada to protect soil base saturation (Ouimet et al. 2006). Critical loads of acidity were determined using a regional default $K_{\text {gibb }}\left(\log K_{\text {gibb }}=9.0\right.$; Ouimet $e t$ al. 2006) and site-specific values estimated assuming that the exchange of base cations between soil and soil solution was in steady-state. The exchange equilibrium was described using the Gaines-Thomas equation assuming the selectivity coefficients for $\mathrm{Ca}^{2+}$ and $\mathrm{Mg}^{2+}$ were zero (UBA 2004).

\section{RESULTS AND DISCUSSION}

\subsection{Soil properties}

There were broad similarities between the study sites as the majority were confined to two BEC zones: coastal western hemlock and mountain hemlock (Tab. 1). Similarly, soils at the majority of sites were podzolic with deep organic horizons, up to $30 \mathrm{~cm}$ at some sites (data not shown). Nonetheless, mineral soil depth to the $\mathrm{C}$ horizon (or bedrock) ranged from $0.11 \mathrm{~m}$ (Thomas Lake) to $0.81 \mathrm{~m}$ (Saturna Island) with a mean depth of $0.40 \mathrm{~m}$ (Tab. 1). The organic matter content (LOI) of the mineral soils ranged from $5-40 \%$ (mean $17 \%$ ), with eleven sites $>15 \%$. The high organic matter content had a significant influence on soil properties, and was highly correlated to soil $\mathrm{pH}(r=0.78 \log \mathrm{LOI})$ and CEC $(r=$ $0.65 \log$ LOI). The soils were acidic (fifteen sites with $\mathrm{pH}<5$ ), with the lowest weighted-average $\mathrm{pH}=4.18$ (Chilliwack). Similarly, the majority of the study sites had low base saturation; mean BS was $16 \%$, ranging from $4 \%$ (Tretheway Lake) to $40 \%$ (Saturna Island). Thirteen sites had BS $<20 \%$, which is characteristic of acid sensitive soils (Tab. 1). In general, soil depth decreased with elevation $(r=-0.59)$ and weighted-average LOI and CEC increased $(r=0.67)$.

The estimated site-specific $\log K_{\text {gibb }}$ ranged from 6.1 to 10.3 with a mean of 8.4 , which is less than the regional default $\left(\log K_{\text {gibb }}=9.0\right)$ used across eastern Canada (Ouimet et al. 2006). Site-specific $K_{\text {gibb }}$ was highly related to $\mathrm{pH}$ and CEC (Figs 2a \& 2b) reflecting the relationship to LOI ( $\mathrm{pH}$ and CEC were highly correlated to LOI). Previous studies have related $K_{\text {gibb }}$ to soil organic matter, suggesting $\log K_{\text {gibb }}=7.6$ for sites with 15-30\% LOI (UBA 2004), which compared well with the current study. In general the soil properties of majority of the study sites (excluding Saturna Island and Campbell River) suggest that the soils in the Georgia Basin are inherently sensitive to soil acidification.

\subsection{Weathering rates}

Estimated (PROFILE) base cation weathering rates ranged from 19 to $351 \mathrm{meq} \mathrm{m}^{-2} \mathrm{y}^{-1}$ (mean $=71 \mathrm{meq} \mathrm{m}^{-2}$ $\mathrm{y}^{-1}$; Tab. 2) and were highly correlated to the mass of soil (soil depth $\times$ bulk density; $r=0.88$ ) excluding one outlier, Campbell River (351 meq $\mathrm{m}^{-2} \mathrm{y}^{-1}$ ), which had the highest proportion of calcite $(2.5 \%)$ an easily weatherable carbonate mineral. The high-elevation sites, Tingle Lake and Thomas Lake, had the lowest weathering rates $\left(<30 \mathrm{meq} \mathrm{m}^{-2} \mathrm{y}^{-1}\right)$ owing to their shallow soils $(<0.30 \mathrm{~m})$ and the relatively low or undetectable quantities of easily weatherable minerals. Further, the majority of the sites $(58 \%)$ had base cation weathering rates $\leq 50$ meq $\mathrm{m}^{-2} \mathrm{y}^{-1}$. Their mineralogy was dominated by quartz $($ mean $=41 \%)$ and plagioclase $($ mean $=35 \%)$, typical of acid sensitive soils (Tab. 2).

Base cation weathering rate was highly related to LOI and clay (Fig. 2c; relationship excludes Campbell River), consistent with other regions of Canada (Whitfield et al. 2010, this issue). This was not surprising as LOI was highly correlated to soil mass $(r=0.88)$ owing to the dependency of bulk density on LOI. Further, clay is strongly related to mineral surface area and is the basis for STA weathering methods (de Vries 1991; UBA 2004). In the current study, clay was correlated to plagioclase $(r=-0.77)$ and chlorite $(r=0.78)$. 

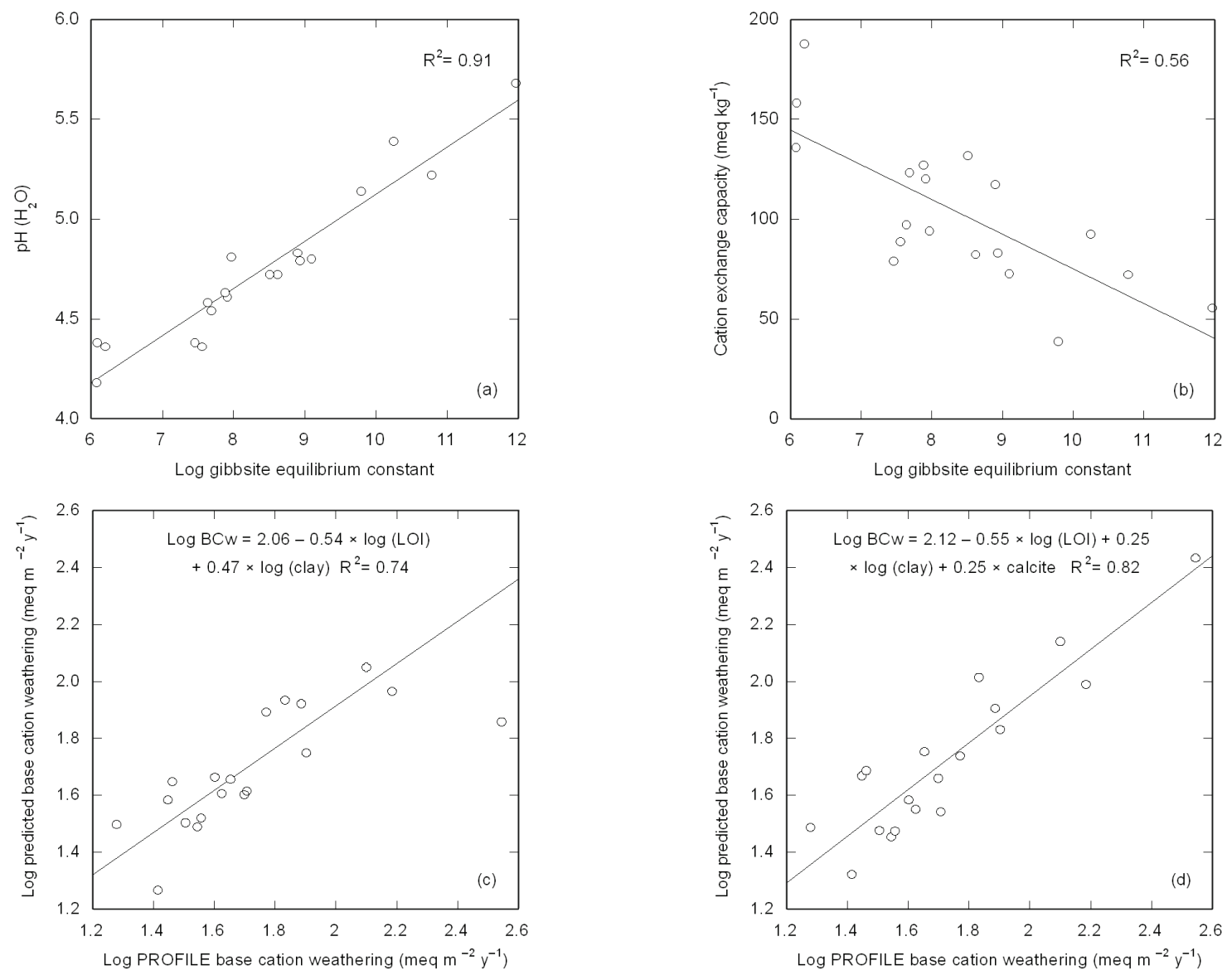

Fig. 2. Relationship between the (a) gibbsite equilibrium constant and $\mathrm{pH}$, (b) gibbsite equilibrium constant and cation exchange capacity, (c) PROFILE estimated base cation weathering and predicted (based on loss-on-ignition and clay), and (d) PROFILE estimated base cation weathering and predicted (based on loss-on-ignition, clay and calcite) for the study sites $(\mathrm{n}=19)$.

Tab. 2. Base cation weathering rate $\left(\mathrm{BCw} ; \mathrm{meq} \mathrm{m}^{-2} \mathrm{y}^{-1}\right)$ and mineralogy $(\%)$ for the study sites in the Georgia Basin, British Columbia. QUA (quartz), KFE (k-feldspar), PLA (plagioclase), HOR (hornblende), MUS (muscovite), CHL (chlorite) and CAL (calcite).

\begin{tabular}{lcccccccc}
\hline Site name & BCw & QUA & KFE & PLA & HOR & MUS & CHL & CAL \\
\hline Saturna Island & 153 & 37.70 & 10.16 & 34.61 & 3.88 & 6.42 & 2.59 & 0.43 \\
Shawnigan Lake & 126 & 44.43 & 4.41 & 28.32 & 6.22 & 2.95 & 5.47 & 0.98 \\
Salt Spring & 77 & 42.25 & 6.89 & 32.60 & 2.62 & 4.51 & 8.49 & 0.50 \\
Campbell River & 351 & 28.24 & 4.67 & 42.93 & 8.67 & - & 8.40 & 2.54 \\
Malcolm Knapp & 80 & 44.54 & 8.28 & 32.35 & 8.57 & - & 1.48 & 0.71 \\
Chilliwack & 35 & 35.41 & 9.36 & 38.58 & 8.27 & 1.96 & 1.16 & - \\
Seymour E & 51 & 24.72 & 7.21 & 34.33 & 3.24 & 4.06 & 9.31 & - \\
Seymour M-L & 28 & 50.94 & 7.06 & 32.83 & 2.35 & 0.69 & 1.93 & 0.51 \\
Capilano & 32 & 40.54 & 5.87 & 36.15 & 12.79 & - & 1.35 & - \\
Coquitlam W & 29 & 49.69 & 7.03 & 32.30 & 4.74 & - & 1.30 & 0.28 \\
Coquitlam 110 & 50 & 40.66 & 7.54 & 31.54 & 11.85 & - & 0.70 & 0.51 \\
Weaver Lake & 59 & 41.61 & 11.8 & 12.96 & 1.36 & - & 22.25 & - \\
Florence Lake & 40 & 36.41 & 4.82 & 39.81 & 13.23 & - & 1.22 & - \\
Tingle Lake & 26 & 45.04 & 4.09 & 40.41 & 6.78 & - & - & - \\
Thomas Lake & 19 & 42.78 & 8.75 & 39.03 & 6.60 & - & 0.53 & - \\
Tretheway Lake & 36 & 32.52 & 5.87 & 35.37 & 16.07 & - & 1.22 & - \\
Kinnear Lake & 42 & 32.96 & 4.28 & 37.65 & 18.49 & - & - & - \\
MASS & 45 & 42.07 & - & 20.70 & 5.84 & - & 19.38 & 1.08 \\
Roberts Creek & 68 & 40.60 & 9.25 & 42.50 & 2.04 & 2.11 & 1.26 & 0.60 \\
Average & 71 & 39.64 & 6.70 & 33.95 & 7.56 & 1.19 & 4.63 & 0.43 \\
\hline
\end{tabular}


Tab. 3. Modelled total (wet and dry) sulphur (S) and nitrogen (N) deposition, critical loads of acidity $(\mathrm{S}+\mathrm{N})$ based on a regional default $K_{\text {gibb }}(\mathrm{A})$ and site-specific values (B; see Tab. 1), and exceedance for the study sites. Units are meq $\mathrm{m}^{-2} \mathrm{y}^{-1}$.

\begin{tabular}{|c|c|c|c|c|c|c|}
\hline \multirow[t]{2}{*}{ Site name } & \multicolumn{2}{|c|}{ Deposition } & \multicolumn{2}{|c|}{ Critical loads } & \multicolumn{2}{|c|}{ Exceedance } \\
\hline & Sulphur & $\overline{\text { Nitrogen }}$ & $\mathrm{A}$ & $\mathrm{B}$ & $\mathrm{A}$ & $\mathrm{B}$ \\
\hline Saturna Island & 10 & 11 & 210 & 193 & & \\
\hline Shawnigan Lake & 13 & 25 & 175 & 163 & & \\
\hline Salt Spring & 14 & 31 & 113 & 105 & & \\
\hline Campbell River & 22 & 17 & 455 & 453 & & \\
\hline Malcolm Knapp & 47 & 114 & 150 & 149 & 12 & 13 \\
\hline Chilliwack & 29 & 88 & 73 & 212 & 44 & \\
\hline Seymour E & 85 & 137 & 123 & 191 & 99 & 31 \\
\hline Seymour M-L & 40 & 74 & 94 & 103 & 20 & 11 \\
\hline Capilano & 34 & 59 & 103 & 158 & & \\
\hline Coquitlam W & 50 & 107 & 93 & 124 & 64 & 33 \\
\hline Coquitlam 110 & 82 & 161 & 118 & 169 & 125 & 74 \\
\hline Weaver Lake & 10 & 56 & 111 & 145 & & \\
\hline Florence Lake & 19 & 79 & 99 & 101 & & \\
\hline Tingle Lake & 30 & 79 & 75 & 261 & 33 & \\
\hline Thomas Lake & 23 & 60 & 65 & 218 & 18 & \\
\hline Tretheway Lake & 24 & 64 & 83 & 94 & 4 & \\
\hline Kinnear Lake & 17 & 47 & 93 & 128 & & \\
\hline MASS & 11 & 24 & 86 & 116 & & \\
\hline Roberts Creek & 36 & 42 & 129 & 117 & & \\
\hline Average & 31 & 67 & 129 & 168 & 46 & 32 \\
\hline
\end{tabular}

The relationship with PROFILE weathering rate was improved by incorporating calcite (Fig. 2d) as a classifier for sites with higher weathering potential.

\subsection{Deposition, critical load and exceedance}

Modelled annual average total (wet and dry) anthropogenic S deposition for the period 2005-2006 ranged from 10 to $85 \mathrm{meq} \mathrm{m}^{-2} \mathrm{y}^{-1}\left(\right.$ mean $\left.=31 \mathrm{meq} \mathrm{m}^{-2} \mathrm{y}^{-1}\right)$, compared with 11-162 meq m $\mathrm{m}^{-2} \mathrm{y}^{-1}$ (mean $=67 \mathrm{meq} \mathrm{m}^{-2}$ $\mathrm{y}^{-1}$ ) for total reduced and oxidised $\mathrm{N}$ deposition (Tab. 3 ). Sulphur deposition was approximately half that of N; moreover, $\mathrm{N}$ deposition was dominant at all study sites except Campbell River.

Critical loads of acidity $(\mathrm{S}+\mathrm{N})$ for forest soils were estimated using a regional default $(\log ) K_{\text {gibb }}(=9.0)$ and estimated site-specific values (Tab. 1). Critical loads based on the default $K_{\text {gibb }}$ ranged from 65 to $455 \mathrm{meq}$ $\mathrm{m}^{-2} \mathrm{y}^{-1}$ (mean $=129$ meq $\mathrm{m}^{-2} \mathrm{y}^{-1}$, Tab. 3) with a large proportion of the sites $<100$ meq m$^{-2} \mathrm{y}^{-1}(\mathrm{n}=9)$. Tingle Lake, Thomas Lake and Chilliwack had the lowest critical loads owing to their relatively low weathering rates. Deposition exceeded critical loads at nine sites (mean = 46 meq $\mathrm{m}^{-2} \mathrm{y}^{-1}$ ); dominated by the high-elevation catchments (Tingle Lake, Thomas Lake and Tretheway Lake) and sites close to Vancouver (Chilliwack, Seymour, Coquitlam and Malcolm Knapp) under high deposition.

Critical loads based on site-specific $K_{\text {gibb }}$ values ranged from 94 to $453 \mathrm{meq} \mathrm{m}^{-2} \mathrm{y}^{-1}$ (mean $=1689 \mathrm{meq}$ $\mathrm{m}^{-2} \mathrm{y}^{-1}$, Tab. 3), with only one site $<100$ meq $\mathrm{m}^{-2} \mathrm{y}^{-1}$. The site-specific $K_{\text {gibb }}$ values resulted in significant changes in critical loads at some sites, e.g., Tingle Lake, Thomas Lake and Chilliwack shifted from the lowest to the highest critical loads owing to the very low site-specific $K_{\text {gibb }}\left(\log K_{\text {gibb }} \sim 6\right)$, which resulted in high critical leaching (Eqn 2). Deposition exceeded critical loads at five sites (mean $=32$ meq $\mathrm{m}^{-2} \mathrm{y}^{-1}$ ) predominantly receiving the highest deposition loads (Tab. 3).

Depending on the approach, exceedance was estimated at five-nine (26-46\%) of the study sites. Although based on only 19 sites, the results are in general agreement with regional assessments for the Georgia Basin (showing 32-42\% exceedance: Nasr et al. 2010, this issue), Canada (Carou et al. 2008) and similar site-specific studies for the Athabasca Oil Sands Regions (34-62\% exceedance: Whitfield et al. 2010; this issue).

\subsection{Uncertainties}

The effects-based critical load approach is well established and the SSMB model has been widely applied across Europe and North America. Nonetheless it is inevitable that there are uncertainties associated with any model application. These can be roughly grouped into two categories: (a) uncertainties owing to model structure, and (b) model parameters. Uncertainties in the SSMB model structure are beyond this study, and to some extent are implicitly axiomatic in a simplified mass balance approach. Uncertainties in SSMB model inputs have been widely discussed (e.g., see Hall et al. 2001b; Skeffington 2006; Li \& McNulty 2007). The relationship between the critical chemical limit and the 'harmful effect' is one of the largest sources of uncertainty (see Løkke et al. 1996; Reinds et al. 2008). A $\mathrm{Bc}: \mathrm{Al}=1$, considered to represent a 50:50 risk of negative impacts on tree growth or nutrition, is the default value commonly used in Europe (Cronan \& 
Gringal 1999, Hall et al. 2001a). However, to be consistent with previous studies in Canada, it was deemed that a $\mathrm{Bc}: \mathrm{Al}=10$ (to preserve soil base saturation) was more appropriate for the Georgia Basin.

Uncertainties in critical load are also primarily associated with the base cation weathering rate (Skeffington 2006, Li \& McNulty 2007). In the current study, weathering rates were estimated using the PROFILE model; the uncertainties and merits of PROFILE have been widely debated (Hosdon et al. 1996, 1997; Barkman \& Alveteg 2001; Hodson 2002). PROFILE is sensitive to soil moisture content, soil mass and mineral surface area (Barkman \& Alveteg 2001). In the current study, sitespecific soil moisture was unavailable, instead default values ranged between 0.30 and $0.35 \mathrm{~m}^{3} \mathrm{~m}^{-3}$ depending on the amount of site precipitation. Similarly, estimates of bulk density and surface area were based on limited observations of LOI and particle size analysis (respectively). Nonetheless, the estimated base cation weathering rates were in agreement with previous studies in Canada (Watmough et al. 2005, Whitfield et al. 2006); shallow soils with little or no weatherable minerals had the lowest weathering rates. Moreover, the PROFILEbased weathering rates showed the expected relationships with LOI and texture (clay).

There is considerable uncertainty on the long-term fate of $\mathrm{N}$ in forest catchments. In the current study, $\mathrm{N}$ input parameters were based on regional defaults owing to the limit observations. Nonetheless, the parameter values were consistent with widely used (and accepted) values (UBA 2004). In general, it is assumed that much of the deposited $\mathrm{N}$ will exceed ecosystem capacity and lead to increased $\mathrm{N}$ leaching and acidification (Galloway 1998). Moreover, $\mathrm{N}$ is the limiting nutrient for plant growth; as such, increased $\mathrm{N}$ deposition may result in changes in plant growth, inter-species relationships and soil-based processes. The eutrophying impact of $\mathrm{N}$ deposition is also evaluated using critical loads (UBA 2004). The estimated empirical critical loads for temperate forests are in the range $10-20 \mathrm{~kg} \mathrm{~N} \mathrm{ha}^{-1} \mathrm{y}^{-1}(5-10$ $\mathrm{kg} \mathrm{N} \mathrm{ha}{ }^{-1} \mathrm{y}^{-1}$ in low deposition areas: Achermann \& Bobbink 2003, UBA 2004). In the current study, eight sites received modelled total $\mathrm{N}$ deposition greater than $10 \mathrm{~kg} \mathrm{~N} \mathrm{ha}^{-1} \mathrm{y}^{-1}$. In concert, a recent study in the Georgia Basin suggested that lichen communities in urban areas are affected by $\mathrm{N}$ deposition (Raymond et al. 2010 , this issue).

\section{CONCLUSION}

Modelled annual average total $\mathrm{S}$ and $\mathrm{N}$ deposition exceeded critical load of acidity for forest soils at fivenine of the study sites (mean exceedance $=32-46 \mathrm{meq}$ $\left.\mathrm{m}^{-2} \mathrm{y}^{-1}\right)$. Despite the limited number of sites $(\mathrm{n}=19)$ and uncertainties inherent in the calculations, the extent of exceedance was similar to other acid sensitive regions in Canada. Moreover, it is clear that high-elevation sites with shallow, acid sensitive, soils and sites close to urban centres under high deposition loads are sensitive to soil acidification. In the current study, sitespecific $K_{\text {gibb }}$ values derived from Gaines-Thomas exchange equilibrium relationships were highly correlated to soil $\mathrm{pH}$ (and LOI) suggesting they better captured the natural variation in soil properties compared with a regional default value $\left(\log K_{\text {gibb }}=9\right)$.

\section{ACKNOWLEDGMENTS}

Financial support for this study was provided by the Georgia Basin Action Plan and Environment Canada Pacific and Yukon region. This research was undertaken, in part, thanks to funding from the Canada Research Chairs Program and a Natural Sciences and Engineering Research Council of Canada Discovery grant. We thank Nick Humphreys, Canadian Forest Service, Rob Hudson, British Columbia Ministry of Forests, Mike Feller, University of British Columbia, and Pat Shaw, Roxanne Vingarzan and Colin diCenzo, Environment Canada, for providing data and logistic support. This article is dedicated to the late Beverley A. Raymond, Environment Canada, for her motivation and foresight to initiate critical loads research in the Georgia Basin.

\section{REFERENCES}

Achermann, B. \& R. Bobbink (Eds). 2003. Empirical critical loads for nitrogen. Environmental documentation No. 164, Swiss Agency for the Environment, Forests and Landscape, Berne, Switzerland: $327 \mathrm{pp}$.

Aherne, J., A. Mongeon \& S.A. Watmough. 2010. Temporal and spatial trends in precipitation chemistry in the Georgia Basin, British Columbia. J. Limnol., 69 (Suppl. 1): 4-10. DOI: 10.3274/JL10-69-S1-02.

Barkman, A. \& M. Alveteg. 2001. Effects of data uncertainty in the Swedish critical load assessment for forest soils. Water Air Soil Pollut., 125: 133-156.

Carou, S., I. Dennis, J. Aherne, R. Ouimet, P.A. Arp, S.A. Watmough, I. DeMerchant, M. Shaw, B. Vet, V. Bouchet \& M. Moran. 2008. A national picture of acid deposition critical loads for forest soils in Canada. CCME Acid Rain Task Group: 6 pp.

Cronan, C.S. \& D.F. Grigal. 1995. Use of calcium/aluminum ratios as indicators of stress in forest ecosystems. J. Environ. Qual., 24: 209-226.

de Vries, W. 1991. Methodologies for the assessment and mapping of critical loads and of the impact of abatement strategies on forest soils. Report 46, DLO The Winand Staring Centre, Wageningen, The Netherlands: 109 pp.

di Cenzo, C. \& M. Lepage. 2003. Application of CMAQ over the Pacific Northwest to determine the significance of the international trans-boundary flows of air contaminants. Second Annual CMAS Models-3 User's Conference One Atmosphere, One Community, One Modelling System: Models-3, October 27-29, Research Triangle Park, Raleigh, North Carolina: $5 \mathrm{pp}$.

Feller, M. \& J. Kimmins. 1984. Effects of clearcutting and slashburning on streamwater chemistry and watershed nutrient budgets in southwestern British Columbia. Wat. Resour. Res., 20: 29-40.

Feller, M.C. 2010. Trends in precipitation and streamwater chemistry in East Creek watershed in southwestern British Columbia, 1971-2008. J. Limnol., 69 (Suppl. 1): 77-91. DOI: 10.3274/JL10-69-S1-09. 
Fraser, D., J. Gaydos, E. Karlsen \& M. Rylko. 2006. Collaborative science, policy development and program implementation in the transboundary Georgia Basin/Puget Sound ecosystem. Environ. Monit. Assess., 113: 49-69.

Galloway, J. 1998. The global nitrogen cycle: changes and consequences. Environ. Pollut., 102: 15-24.

Gibson, J.J., S.J. Birks, D.S. Jeffries, S. Kumar, K.A. Scott, J. Aherne \& D.P. Shaw. 2010. Site-specific estimates of water yield applied in regional acid sensitivity surveys across western Canada. J. Limnol., 69 (Suppl. 1): 67-76. DOI: 10.3274/JL10-69-S1-08.

Grennfelt, P., F. Moldan, M. Alveteg, P. Warfvinge \& H. Sverdrup. 2001. Critical loads - is there a need for a new concept? Water Air Soil Pollut. Focus, 1: 21-27.

Hall, J., B. Reynolds, J. Aherne \& M. Hornung. 2001a. The importance of selecting appropriate criteria for calculating acidity critical loads for terrestrial ecosystems using the simple mass balance equation. Water Air Soil Pollut. Focus, 1: 1-41.

Hall, J., B. Reynolds, S. Langan, M. Hornung, F. Kennedy \& J. Aherne. 2001b. Investigating the uncertainties in the simple mass balance equation for acidity critical loads for terrestrial ecosystems in the United Kingdom. Water Air Soil Pollut. Focus, 1: 43-56.

Helliwell, R., R. Ferrier, C. Evans \& A. Jenkins. 1998. A comparison of methods for estimating soil characteristics in regional acidification models; an application of the MAGIC model to Scotland. Hydrol. Earth Syst. Sci., 2(4): 509-520.

Hodson, M.E., S.J. Langan \& M.J. Wilson. 1996. A sensitivity analysis of the PROFILE model in relation to the calculation of soil weathering rates. Appl. Geochem., 11: 835844.

Hodson, M.E., S.J. Langan \& M.J. Wilson. 1997. A critical evaluation of the use of the PROFILE model in calculating mineral weathering rates. Water Air Soil Pollut., 98: 79104.

Hodson, M.E. 2002. Comments on "Calculations of weathering rate and soil solution chemistry for forest soils in the Norwegian-Russian border area with the PROFILE model" by G. Kopstik, S. Tevedal, D. Aamlid and K. Venn. Appl. Geochem., 17: 117-121.

Johansson, M., R. Suutari, J. Bak, G. Lövblad, M. Posch, D. Simpson, J.-P. Tuovinen \& K. Tørseth. 2001. The importance of nitrogen oxides for the exceedance of critical thresholds in the Nordic countries. Water Air Soil Pollut., 130: 1739-1744.

Li, H. \& S.G. McNulty. 2007. Uncertainty analysis on simple mass balance model to calculate critical loads for soil acidity. Environ. Pollut., 149: 315-326.

Løkke, H., J. Bak, U. Falkengren-Grerup, R.D. Finlay, H. Ilvesniemi, P.H. Nygaard \& M. Starr. 1996. Critical loads of acidic deposition for forest soils: is the current approach adequate? Ambio, 25: 510-516.

Meidinger, D. \& J. Pojar (compilers and editors). 1991. Ecosystems of British Columbia. British Columbia Forest Service, Research Branch. Special Report Series 06: 330 pp.

Melkerud, P.-A., D. Bain \& M. Olsson. 2003. Historical weathering based on chemical analyses of two spodosols in southern Sweden. Water Air Soil Pollut. Focus, 3: 49-61.

Nasr, M., M. Castonguay, J. Ogilvie, B.A. Raymond \& P.A. Arp. 2010. Modelling and mapping critical loads and exceedances for the Georgia Basin, British Columbia, using a zero base-cation depletion criterion. J. Limnol., 69 (Suppl. 1): 181-192. DOI: 10.3274/JL10-69-S1-18.

New, M., M. Hulme \& P.D. Jones. 1999. Representing twentieth century space-time climate variability. Part 1: devel- opment of a 1961-90 mean monthly terrestrial climatology. J. Clim., 12, 829-856.

Nilsson, J. \& P. Grennfelt. 1988. Critical loads for sulphur and nitrogen. Miljørapport 1988:15, NORD 1998:097, Nordic Council of Ministers, Copenhagen, Denmark: 418 pp.

Ouimet, R. \& L. Duchesne. 2005. Base cation mineral weathering and total release rates from soils in three calibrated forest watersheds on the Canadian Boreal Shield. Can. J. Soil Sci., 85: 245-260.

Ouimet, R., P.A. Arp, S.A. Watmough, J. Aherne \& I. DeMerchant. 2006. Determination and mapping of critical loads of acidity and exceedances for upland forest soils in Eastern Canada. Water Air Soil Pollut., 172: 57-66.

Raymond, B.A., T. Bassingthwaighte \& D.P. Shaw. 2010. Measuring nitrogen and sulphur deposition in the Georgia Basin, British Columbia, using lichens and moss. $J$. Limnol., 69 (Suppl. 1): 22-32. DOI: 10.3274/JL10-69-S1-04.

Reinds, G.J., M. Posch, W. de Vries, J. Slootweg \& J.-P. Hettelingh. 2008. Critical loads of sulphur and nitrogen for terrestrial ecosystems in Europe and Northern Asia using different soil chemical criteria. Water Air Soil Pollut., 193: 269-287.

Siltanen, R., M. Apps, S. Zoltai, R. Mair \& W. Strong. 1997. A soil profile and organic carbon data base for Canadian forest and tundra mineral soils. Northern Forestry Centre, Canadian Forest Service, Natural Resources Canada: 50 pp.

Solberg, S., S. Kvindlesland, D. Aamlid \& K. Venn. 2002. Crown condition and needle chemistry of Norway spruce relation to critical loads of acidity in South-East Norway. Water Air Soil Pollut., 140: 157-171.

Skeffington, R.A. 2006. Quantifying uncertainty in critical loads: (a) literature review. Water Air Soil Pollut., 169: 3-24.

Strang, D., J. Aherne \& D.P. Shaw. 2010. The hydrochemistry of high-elevation lakes in the Georgia Basin, British Columbia. J. Limnol., 69 (Suppl. 1): 56-66. DOI: 10.3274/ JL10-69-S1-07.

UBA 2004. Manual on methodologies and criteria for modelling and mapping critical loads \& levels and air pollution effects, risks and trends. UNECE Convention on Longrange Transboundary Air Pollution, Federal Environmental Agency (Umweltbundesamt), Berlin: 254 pp.

van der Salm, C. 2001. Assessment of the regional variation in weathering rates of loess and clay soils in the Netherlands. Water Air Soil Pollut., 131: 217-243.

Warfvinge, P. \& H. Sverdrup. 1992. Calculating critical loads of acid deposition with PROFILE - a steady-state soil chemistry model. Water Air Soil Pollut., 63: 119-143.

Watmough, S.A., J. Aherne, C. Alewell, P. Arp, S. Bailey, T. Clair, P. Dillon, L. Duchesne, C. Eimers, I. Fernandez, N. Foster, T. Larssen, E. Miller, M. Mitchell \& S. Page. 2005. Sulphate, nitrogen and base cation budgets at 21 forested catchments in Canada, the United States and Europe. Environ. Monit. Assess., 109: 1-36.

Wiens, J.H. 1987. Sensitivity of western and northern Canada soils and geology to acidic input. Victoria, B.C.: Technical Committee for the Long-Range Transport of Atmospheric Pollutants in Western and Northern Canada, Coordinating Committee on Soil and Geology Sensitivity Mapping (Canada).

Whitfield, C.J., S.A. Watmough, J. Aherne \& P.J. Dillon. 2006. A comparison of weathering rates for acid-sensitive catchments in Nova Scotia, Canada and their impact on critical load calculations. Geoderma, 136: 899-911.

Whitfield, C.J., J.Aherne, S.A. Watmough \& M. McDonald. 2010. Estimating the sensitivity of forest soils to acid deposition in the Athabasca Oil Sands Region, Alberta. $J$. Limnol., 69 (Suppl. 1): 201-208. DOI: 10.3274/JL10-69S1-20. 